\title{
Aktualne problemy edukacji uczniów z niepełnosprawnością w percepcji nauczycieli w różnych formach kształcenia specjalnego
}

KEY WORDS

student with a disability, special education, special education teacher

\begin{abstract}
Lipińska-Lokś Jolanta, Aktualne problemy edukacji uczniów z niepełnosprawnością $w$ percepcji nauczycieli w różnych formach kształcenia specjalnego [Current Problems of the Education of Students with Disabilities in The Perception of Teachers Engaged in Various Forms of Special Education System]. Kultura - Społeczeństwo - Edukacja nr 1(7), 2015, Poznań 2015, pp. 159-177, Adam Mickiewicz University Press. ISBN 978-83-232-2944-5. ISSN 2300-0422

Education of students with disabilities is a challenge for teachers engaged in various forms of special education. Due to recognizing the limitations and problems connected with education of such a diverse group of students, new solutions are sought.This article compares the higher education systems between China and Ukraine
\end{abstract}

\section{Wprowadzenie}

Edukacja uczniów z niepełnosprawnością stanowi integralną część polityki oświatowej w Polsce. Jej realizacja jest unormowana prawnie. Na przestrzeni lat poddawane były dyskusji liczne i różnorodne kwestie $\mathrm{z}$ tą edukacją związane, jednak wciąż stanowi ona źródło refleksji zarówno teoretyków, jak i - a może przede wszystkim - praktyków, którzy na co dzień zmagają się z realizacją zadań wobec ucznia z niepełnosprawnością. Bywa, że często dostrzegają oni słabe jej strony, występujące w niej/z nią problemy.

Nie powinno to dziwić, w grę bowiem wchodzi złożoność samego kształcenia specjalnego - kształcenia, które wymaga specjalnego, wyjątkowego podejścia. Dzieje się to za sprawą adresata specjalnych działań edukacyjnych - ucznia z niepełnosprawnością. Uczeń ten łamie przyjęte standardy realizowane $\mathrm{w}$ szkole masowej, najczęściej charakteryzującej się schematyzmem oddziaływań, nakiero- 
waniem na przeciętność ucznia. Doświadcza on niepełnej sprawności, odchyleń w stanie zdrowia i rozwoju, co sprawia że jego bio-psycho-społeczne funkcjonowanie jest często w sposób istotny zaburzone. Mimo że człowiek z niepełnosprawnością ma wiele/więcej cech wspólnych z osobami, których problem ograniczeń rozwojowych nie dotyczy, to jednak cechy swoiste wynikające $\mathrm{z}$ bycia nie w pełni sprawnym decydują o ukształtowaniu się jego potrzeb specjalnych. Potrzeby te z kolei wymuszają na systemie kształcenia ogólnie, a na każdej szkole w szczególności, dostosowanie się do indywidualnych potrzeb ucznia realizującego w jej murach obowiązek szkolny. Prawo oświatowe jednoznacznie określa konieczność udzielenia uczniowi ze specjalnymi potrzebami edukacyjnymi pomocy psychologiczno-pedagogicznej, wskazuje warunki i zasady jej realizowania ${ }^{1}$. Szkoła ma obowiązek zabezpieczenia jednego z podstawowych praw dziecka - prawa do edukacji ${ }^{2}$. Ma poczynić wszelkie starania, podjąć odpowiednie specjalistyczne oddziaływania o charakterze opiekuńczym, socjalizacyjnym, wychowawczym, dydaktycznym, rewalidacyjnym, by uczeń, wychowanek, podopieczny mógł mieć zapewniony wszechstronny, optymalny, na miarę swych możliwości rozwój ${ }^{3}$.

\section{Formy kształcenia specjalnego uczniów z niepełnosprawnością}

Troska o ucznia $\mathrm{z}$ niepełnosprawnością realizowana jest $\mathrm{w}$ różnych formach kształcenia specjalnego. Liczebność i zróżnicowanie grupy uczniów z niepełnosprawnością spowodowały rozwój zróżnicowanych form ich edukacji. Uczeń $\mathrm{z}$ niepełnosprawnością może być edukowany zarówno $\mathrm{w}$ tradycyjnej formie kształcenia specjalnego - segregacyjnej - jaką jest szkoła specjalna, jak i w ramach kształcenia specjalnego o charakterze integracyjnym.

Wśród dostępnych możliwości tego typu kształcenia najczęściej obecnie wymienia się edukację integracyjną ( $w$ postaci klas integracyjnych), edukację inkluzyjną (włączającą pojedynczych uczniów w struktury klas w szkole powszechnej, nie-integracyjnych) oraz klasy specjalne w szkołach masowych (Szumski, 2006). Należy dodatkowo wspomnieć o nauczaniu indywidualnym ucznia z niepełnosprawnością, który z powodu swojej sytuacji zdrowotnej i ży-

\footnotetext{
${ }^{1}$ Por. Rozporządzenie Ministra Edukacji Narodowej z dnia 30 kwietnia 2013 r. w sprawie zasad udzielania i organizacji pomocy psychologiczno-pedagogicznej w publicznych przedszkolach, szkołach i placówkach, Dz. U. 2013, poz. 532, z późn. zm.

${ }^{2}$ Por. Konstytucja Rzeczypospolitej Polskiej, 1997, Dz. U. 1997, Nr 78, poz. 483.

${ }^{3}$ Por. Ustawa o systemie oświaty z dnia 7 września 1991 r., tekst jednolity, Dz. U. 2004, Nr 256, poz. 2572.
} 
ciowej nie jest w stanie realizować obowiązku szkolnego, będąc obecnym w murach szkoły. Uczeń nauczany w swym środowisku domowych przez dochodzących nauczycieli jest jednak uczniem danej szkoły, przynależy do grupy klasowej, jest odwiedzany przez rówieśników - kolegów ze szkoły, bywa „okolicznościowo" w szkole. To wszystko sprawia, że forma jego nauczania uznana może być za formę integracyjną kształcenia specjalnego. Idąc tym torem myślenia, można dopatrywać się znamion integracji nauczania dzieci pełno- i niepełnosprawnych w przypadku szkół specjalnych. Nie są rzadkością bowiem szkoły specjalne, które można by określić otwartymi na środowisko lokalne, współpracującymi właśnie w tym środowisku ze szkołą nie-specjalną. Uczniowie tych dwóch szkół znają się, wspólnie uczestniczą $\mathrm{w}$ organizowanych dla nich imprezach, ich nauczyciele współpracują ze sobą, wspólnie realizują projekty, często wzajemnie się wspierają (por. Lipińska-Lokś, 2014: 252-260).

Funkcjonowanie licznych i zróżnicowanych form edukacji uczniów z niepełnosprawnością skłania do analiz mających na celu ich porównywanie, uwzględniając pewne perspektywy tych porównań, a mianowicie:

a) perspektywa czasu, która pozwala na ukazanie genezy kształcenia specjalnego, dynamiki rozwoju szkół specjalnych - tradycyjnych, zmian zachodzących w ich funkcjonowaniu. Ta przeszłość łączy się z teraźniejszością, cechującą się współistnieniem formy segregacyjnej i form integracyjnych kształcenia specjalnego, o których wyborze decyduje stan dziecka - jego ograniczenia, możliwości sprostania tym ograniczeniom wskazywanej w wyborze szkoły, opinie rodziców. Perspektywa czasu pozwala także spoglądać w przyszłość oceniającą efektywność edukacji uczniów z niepełnosprawnością w danej formie kształcenia, ukazującą rolę danej formy w zmieniającej się edukacyjnej rzeczywistości;

b) perspektywa postrzegania wad i zalet poszczególnych form edukacji specjalnej uczniów $\mathrm{z}$ niepełnosprawnością. Porównywanie form uwzględniające ściśle określone kryteria pozwala rzeczywiście na ocenę każdej z możliwości edukacji uczniów ze specjalnymi potrzebami edukacyjnymi. Nie mniej jednak należy przyznać, że nie ma jednej formy idealnej kształcenia specjalnego, a o wyborze drogi edukacyjnej każdego dziecka z niepełnosprawnością powinno decydować przede wszystkim jego dobro, jego swoiste ograniczenia i zachowane, przejawiane możliwości oraz jego specjalne potrzeby. Różnorodność form stanowi szansę właściwego pokierowania karierą edukacyjną ucznia, podobnie jak i możliwość zmiany danej formy na inną w przypadku zaistnienia takiej potrzeby, stwierdzenia, że inna forma $z$ właściwymi sobie warunkami realizacji edukacji wyjątkowego ucznia będzie dla niego korzystniejsza;

c) perspektywa świadomości społecznej dotyczącej sytuacji życiowej osób z niepełnosprawnością. Ta świadomość społeczna leży u podstaw nastawienia 
społeczeństwa wobec osób z niepełnosprawnością. Dana postawa - ze swym komponentem poznawczym - wiedzy na temat niepełnosprawności i osób jej doświadczających, $\mathrm{z}$ komponentem emocjonalnym, stanowiącym o stosunku do tej kategorii osób oraz z komponentem behawioralnym, przejawiającym się działaniami, zachowaniem wobec tych osób - na przestrzeni wieków różna - przyczyniała się do postrzegania osób „innych”, ich funkcjonowania, potrzeb. Analiza funkcjonujących postaw społecznych, form kształcenia specjalnego pozwala na wskazanie długiej drogi, jaką musiały/muszą przejść osoby z niepełnosprawnością - od braku przyznawania im prawa do życia, poprzez izolację, segregację do integracji, a właściwie jeszcze dalej - i wciąż daleko, bo do normalizacji, do takiego stanu, kiedy niepełnosprawność będzie jedną z wielu cech człowieka, obok jego płci, wieku, koloru skóry czy oczu, poziomu wykształcenia czy zainteresowań.

Choć to odległa przyszłość, ale warto o niej myśleć, szczególnie gdy refleksja nakazuje nam ocenę aktualnej rzeczywistości, w której dostrzega się m.in. problemy w edukacji uczniów z niepełnosprawnością.

\section{Obszary problemów edukacji uczniów z niepełnosprawnościa}

Wyodrębnienie obszarów problemów dostrzeganych przez nauczycieli uczniów z niepełnosprawnością możliwe było dzięki analizie treści literatury przedmiotu oraz - przede wszystkim - realizacji badań własnych autorki niniejszego opracowania. Zaprezentowane wyniki stanowią tylko fragment badań o charakterze jakościowym, z wykorzystaniem metody indywidualnych przypadków, dotyczących doświadczeń nauczycieli w edukacji uczniów z niepełnosprawnością (różnego rodzaju i stopnia), zrealizowanych w grupie nauczycieli uczniów z niepełnosprawnością zatrudnionych w szkole specjalnej, w klasie integracyjnej, w szkole powszechnej w klasie nie-integracyjnej oraz realizujących nauczanie indywidualne. Odwołano się do materiału badawczego uzyskanego w wyniku przeprowadzenia wywiadów z 21 nauczycielami uczącymi w zielonogórskich szkołach podstawowych w latach 2010-2013. Dzięki zgromadzonemu materiałowi udało się zrealizować cel poznawczy badań: diagnoza doświadczeń nauczycieli w nauczaniu dzieci z niepełnosprawnością i odpowiedzieć na szczegółowe pytanie problemowe: $\mathrm{Z}$ jakimi problemami w edukacji uczniów z niepełnosprawnością spotykają się ich nauczyciele?

Badania ukazały, że nauczyciele dostrzegają liczne i różnorodne problemy w edukacji uczniów z niepełnosprawnością. Problemy te dotyczą: 
a) unormowań prawnych edukacji uczniów $\mathrm{z}$ niepełnosprawnością,

b) zapewnienia odpowiednich warunków natury technicznej pobytu ucznia z niepełnosprawnością w szkole,

c) organizacji procesu nauczania i metodyki ortodydaktyki,

d) kompetencji nauczyciela ucznia $\mathrm{z}$ niepełnosprawnością oraz możliwości wsparcia nauczyciela w jego pracy,

e) współpracy szkoły z rodzicami uczniów zarówno pełnosprawnych, jak i uczniów z niepełnosprawnością (por. Twardowski, 2014: 119-130).

Warto przyjrzeć się wymienionym problemom, tym bardziej, że każda $\mathrm{z}$ ich grup, w mniejszym bądź większym stopniu, ale zawsze obecna jest w wypowiedziach nauczycieli uczniów z niepełnosprawnością poproszonych o wyrażenie swych opinii w realizowanych badaniach.

\section{"(...) w rozporządzeniach jedno jest jasne i pewne, że się zmienią wcześniej lub później (...)"}

Podstawą wszelkiej działalności edukacyjnej są unormowania prawne. Na nie właśnie zwracają uwagę badani. Ci doświadczeni stażem pracy nauczyciele wspominają np. początki edukacji integracyjnej, braki w przepisach, różną ich interpretację, liczne wątpliwości co do samej słuszności realizacji idei społecznej integracji osób niepełnosprawnych już na etapie szkoły, godziny rozmów przekonujących w zasadzie i siebie, i rodziców dzieci pełno- i niepełnosprawnych, tworzenie w trudach warunków technicznych przebywania ucznia „innego” w szkole ogólnodostępnej, poszukiwanie metod pracy z nim. Młodsi stażem nauczyciele cenią sobie, że prawodawca odpowiada na potrzeby społeczne, jasno precyzuje prawa i obowiązki szkoły, uczniów, dyktuje warunki realizacji nauczania, pomocy. Przyznają się jednak do luk w wiedzy na temat unormowań prawnych, usprawiedliwiając się jednocześnie osobą dyrektora, który

(...) wie na pewno i powie co i jak (...) na radzie pedagogicznej, albo w biegu na korytarzu, (...), albo wywiesi coś w pokoju nauczycielskim, by rzucić okiem.

Co ciekawe, kojarzą przepisy najczęściej z ich zmianą - albo tą, która właśnie następuje, albo nastąpić ma w niedalekiej przyszłości:

(...) w rozporządzeniach jedno jest jasne i pewne, że się zmienią wcześniej lub później, i tylko szkoda, bo część rzeczy jest ok., (...) no i człowiek się już przyzwyczaił, nauczył się czegoś, coś sobie szkoła wypracowała, a tu znowu ktoś ma pomysł, podobno dobry, (...) nieraz mam wrażenie, że przepisy „udoskonalają” ludzie, którzy w szkole nie byli lub rzadko bywali (...). 
Wiele emocji wzbudza ten pewien poziom, jak to określił nauczyciel

rozmijania się idei z rzeczywistością (...), papier wszystko przyjmie a człowiek potem musi to wykonać (...).

Gorącym tematem dyskusji w czasie realizacji badań była kolejna zmiana w rozporządzeniu o pomocy psychologiczno-pedagogicznej uczniom ze specjalnymi potrzebami edukacyjnymi. Nauczyciele szkół masowych mieli więcej wątpliwości, bardziej poczuli się niepewni w swych działaniach, częściej wskazywali na konieczność „poważnego przemyślenia tematu”, „nauczenia się czegoś nowego" (Lipińska-Lokś, 2014: 248-264).

\section{„Podejście indywidualne do ucznia zawsze było, jest i będzie, to normalne (...)"}

Podobne opinie nauczyciele ci głosili $\mathrm{w}$ sytuacji, kiedy $\mathrm{w}$ ich szkole miało pojawić się pierwsze, czy też kolejne dziecko z niepełnosprawnością. Wątpliwość zawsze dotyczyła gotowości szkoły do przyjęcia takiego dziecka i poradzenia sobie z prowadzeniem go, a więc warunków technicznych, barier architektonicznych oraz kompetencji merytoryczno-metodycznych nauczycieli. W opinii nauczycieli nie zawsze łatwo jest (z powodów obiektywnych, finansowych) technicznie sprostać specjalnym potrzebom ucznia z niepełnosprawnością (Apanel, 2014: 247-257), choć jest to zdecydowanie prostsze w porównaniu z przygotowaniem się, jak to określiła nauczycielka z klasy integracyjnej, „mentalnie”, wskazując na konieczność zaakceptowania takiego ucznia no i siebie w roli nauczyciela „ucznia trudnego, wymagającego inaczej i czegoś innego”. Badania wykazały różnice $\mathrm{w}$ opiniach nauczycieli edukacji integracyjnej (klas integracyjnych) i edukacji włączających. Pewniej czują się ci, którzy uczą w teamie z drugim nauczycielem, choć zawsze pojawia się kwestia innych wspomagających specjalistów. Na marginesie należy dodać, że samo wsparcie oceniane jest raczej negatywnie, nauczyciele $\mathrm{w}$ zdecydowanej większości przypadków narzekają na jego brak lub niedosyt, w efekcie czego często czują się osamotnieni w swych działaniach, narażeni na porażkę zawodową. „Inność” ucznia nie stanowi z kolei większego problemu dla nauczycieli szkół specjalnych:

Przecież w naszej szkole wszyscy uczniowie są inni w porównaniu z uczniami ze szkół „normalnych" i ja, pracując w tej szkole, wiem, że on taki jest, i muszę dostosować uczenie, metody do jego poziomu. 
Podejście indywidualne do ucznia zawsze było, jest i będzie, to normalne (...) IPET czy nie IPET - nazwa nie ma znaczenia, bo chodzi przecież o to, by każdy uczeń był odpowiednio zaopiekowany, bo to nie Down, tylko Asia z takim i takim problemem i to Asię trzeba nauczyć, poddać tej i tej terapii dostosowanej do niej (...).

Nauczyciele uczący w szkole specjalnej charakteryzuje także większe poczucie wsparcia w swojej pracy. Deklarują oni, że

koleżanka zna tego ucznia, pracuje z nim, ma te same problemy, wypracowała sobie już sposób radzenia sobie z tym problemem, więc i ja już to wiem i mogę to wykorzystać.

\section{„(...) wygadać się będzie można (...)"}

Dodać należy, że wszyscy badani nauczyciele wskazują na - z jednej strony: konieczność podążania za uczniem, reagowania na jego potrzeby, doskonalenia swojego warsztatu pracy, z drugiej - na konieczność istnienia możliwości otrzymania wsparcia $\mathrm{w}$ sytuacji nieradzenia sobie z problemami w edukacji uczniów $\mathrm{z}$ niepełnosprawnością. Ich wypowiedzi stanowią swoisty apel o dostrzeżenie potrzeby wręcz systemowego wsparcia nauczyciela ucznia ze specjalnymi potrzebami edukacyjnymi, co pozwoli na naturalizację proszenia o pomoc i korzystania $\mathrm{z}$ niej.

W odpowiedziach na pytanie, kto miałby tego wsparcia nauczycielom udzielać, pojawiają się zarówno inni nauczyciele - specjaliści, bardziej doświadczeni, którzy mogliby udzielać porad, instruować i ukazywać możliwości praktycznego rozwiązania napotkanego problemu, jak i rozwiązania „instytucjonalne”:

(...) ośrodek metodyczny, ale taki prawdziwy z fachowcami, gdzie nie tylko zarzucą literaturą, ale konkretnie wskażą kierunek, zaproponują konkretne działanie (...), wygadać się będzie można (...).

Ten aspekt możliwości podzielenia się z innymi swoimi opiniami, wątpliwościami, problemami często w rozmowach się pojawia, co wskazuje na ogromną potrzebę być może tworzenia grup samopomocowych:

Jak sobie nie radzę, to zapraszam koleżanki na kawę, spotkamy się, pogadamy, coś wymyślimy razem i już nam lepiej (...).

Mamy takie towarzystwo... wzajemnej adoracji (tu: śmiech rozmówczyni - przyp. J. L.-L.), rozumiemy się, co dwie głowy..., zaspokajamy też potrzebę kontaktów towarzyskich, bo $\mathrm{w}$ tym zabieganiu, trudno o relaks, a tu przyjemne z pożytecznym (...). 


\section{"(...) oswoić rodzica z sytuacja (...)"}

W związku z tym, że rzeczywistość szkolną tworzą nie tylko nauczyciele i uczniowie, wprost zapytano $\mathrm{w}$ badaniach o występowanie problemów związanych z rodzicami uczniów z niepełnosprawnością. Analiza uzyskanych wyników pozwala na sformułowanie kilku wniosków:

a) nauczyciele zdają sobie sprawę z prawa rodziców do obecności w szkole, do współpracy $\mathrm{z}$ nauczycielami w kwestiach dotyczących ich dzieci i samego funkcjonowania szkoły;

b) wielu nauczycieli zadowolonych by było, gdyby współpraca rodziców ze szkołą dla dobra dziecka była wręcz nakazanym rodzicom obowiązkiem, co może zwiększyć efektywność oddziaływań terapeutycznych i dydaktycznych;

c) nauczyciele spotykają się $\mathrm{z}$ różnymi postawami rodziców wobec szkoły i nauczycieli, cenią sobie oczywiście otwartość rodziców na współdziałanie, ich pozytywne nastawienie wobec działań nauczycieli, radosne - mimo trudów życia - usposobienie, woleliby unikać rodziców roszczeniowych, wiecznie ze wszystkiego niezadowolonych i tych, którzy „mają to dziecko i uważają, że już dla niego wystarczająco wiele zrobili (...), szkoła niech się wykaże (...)";

d) brak chęci współpracy rodziców z nauczycielami jest ogromnym problemem, podobnie jak sytuacja, gdy rodzic próbuje narzucić szkole swoje zdanie, działania, nie pozwalając szkole na ukazanie innych równie dobrych rozwiązań oraz udzielenie pomocy zarówno dziecku, jak i jego rodzinie;

e) nauczyciele doceniają rodziców jako partnerów interakcji, współpracy, cenią sobie ich wiedzę, umiejętności, postawę życiową, chcą z doświadczeń rodzicielskich korzystać w swej pracy.

Nauczyciele uczący w formach integracyjnych wskazują dodatkowo w swoich wypowiedziach na problemy z rodzicami uczniów pełnosprawnych, szczególnie z tymi, którzy nie czuli się współdecydentami w sytuacji, gdy klasa ich „zdrowego”, „normalnego” dziecka stała się klasą integracyjną. Rodzice ci musieli być informowani, instruowani, przekonywani, często wręcz pouczani, wszystko po to by: „nie torpedowali każdego zebrania”, „nie wpajali swych poglądów przyjaznym inności dzieciom”, „nie atakowali rodziców dzieci trudnych”. Wielu nauczycieli sugerowało, że potrzebny był czas, by „oswoić rodzica z sytuacją (...), inny nie znaczy gorszy, (...), że jego dziecko też wiele zyskuje” (Lipińska-Lokś, 2014b).

Wśród problemów dostrzeganych przez nauczycieli pracujących z uczniem z niepełnosprawnością znajdują się także i te, które nieobce są również wszystkim innym nauczycielom, choć rzeczywiście w przypadku pedagogów specjal- 
nych, nauczycieli włączających, nauczycieli uczących w klasach integracyjnych czy też realizujących nauczanie indywidualne skala tych problemów, ich nasilenie są zdecydowanie większe.

\section{„Papiery, góra papierów (...)” - problem wszystkich nauczycieli}

Badani nauczyciele zapytani o najczęstszy powód zdenerwowania w pracy wskazują na biurokratyzację zawodu nauczycielskiego. Czują się wręcz przeciążeni $\mathrm{z}$ tego powodu:

papiery, góra papierów (...) nieraz mam wrażenie że zupełnie nieuzasadnione jest ich produkowanie, nie widzę sensu powielania różnych informacji w różnych miejscach, (...) mam uczyć, a nie być sekretarką, pisać wiecznie sprawozdania.

(...) początek i koniec roku szkolnego, (...) czas, gdzie człowiek mało śpi, bo albo coś pisze, albo myśli co napisać, co jeszcze do udokumentowania zostało (...), często się zastanawiam, czy to ktoś tak dokładnie czyta, jak ja dokładnie opisałam.

Wielu z nauczycieli wspomina „istną gonitwę” za zdobyciem kolejnego stopnia awansu zawodowego:

Miałam tyle kwitów, że w dwóch siatkach je niosłam.

Przez rok - mam wrażenie - że nie byłam nauczycielem, tylko jaką́s maszynką do produkowania dokumentów, które miały świadczyć o mojej wartości i przydatności do zawodu.

W wypowiedziach nauczycieli pojawia się także kwestia elektronicznego dziennika. Zdają sobie sprawę z tego, że zawsze zmiany, początki wprowadzania czegoś nowego nie są łatwe, niemniej jednak konieczność prowadzenia podwójnie dziennika, samo wprowadzanie do e-dziennika danych traktują jako dodatkową uciążliwą czasowo pracę, która nie zawsze spotyka się z docenieniem:

Większość rodziców moich uczniów przyzwyczaiła się do tego, co i jak było, niechętnie zaglądają do e-dziennika, preferują kontakt osobisty, obawiają się, że w tym e-dzienniku nie ma wszystkiego, że nie jest na bieżąco uzupełniany (...) no ...tak jest w tym trochę racji.

\section{„Nauczyciel to ma klawe życie (...)"?}

Nauczyciele zmęczeni są nie tylko przeciążeniem „pracą biurową”. Wiele negatywnych emocji przeżywają także w związku ze świadomością tego, jak są z regu- 
ły postrzegani przez tzw. ogół społeczeństwa. Powszechnie obowiązująca opinia głosi, że: „nauczyciel to ma klawe życie”, „kilka godzin zabawy w pracę w pracy, masa dni wolnych, urlop i zimą i latem, i to jak długi - dwa miesiące laby, żyć nie umierać”. Wszyscy badani nie są $\mathrm{w}$ stanie zgodzić się z tą opinią, choć niejednokrotnie przyznają, że rzeczywiście, patrząc $\mathrm{z}$ boku, nie znając istoty pracy nauczyciela można odnieść takie wrażenie. Jednocześnie wielu zaczyna się zastanawiać:

Skoro tak dobrze nam nauczycielom, jak twierdzi kuzyn, to dlaczego on nie został nauczycielem, skoro skończył polonistykę, mógłby uczyć w szkole, a nie uczy, tylko ciężko pracuje fizycznie w jakimś markecie?

Dlaczego rodzic mojego ucznia nie dostrzega tego, że pracę zabieram do domu i kiedy on odpoczywa po swojej ciężkiej pracy, to ja relaksuję się do 2-3 w nocy, sprawdzając pracę klasową, przygotowując się do zajęć, wypełniając kolejne dokumenty jego dziecka?

(...) obyś cudze dzieci uczył - chyba coś jest w tym przekleństwie zawodu nauczyciela (...) tak, zdarzyło mi się iść do pracy i myśleć: za jakie grzechy sama siebie skazuję na taką mękę? (...).

W wielu wypowiedziach wybrzmiewa właściwie żal do „opinii społecznej”, że nie dostrzega trudów pracy nauczyciela związanych z koniecznością poświęcania najczęściej „dużo więcej czasu niż ustawa przewiduje” na realizację swych zadań zawodowych, że nie widzi podejmowania zadań dodatkowych, poza godzinami pracy, w dni wolne w trosce o ucznia, jego rozwój, dobre samopoczucie; że nie docenia zaangażowania nauczyciela, jego wysiłków, reprezentowanej postawy zawodowej,

(...) tak łatwo krytykować.

(...), ale najprościej, tylko czyhać na błąd, rozliczać, narzekać, a samemu (...) przyglądać się, umywać ręce, (...) nie to nie jego (rodzica - przyp. J. L.-L.) sprawa.

Obok wypowiedzi przepełnionych smutkiem, żalem są i te pełne złości, pretensji:

Wie (rodzic - przyp. J.L.-L.), jakie ma dziecko, sam sobie zupełnie nie radzi, ale ja (nauczyciel - przyp. J. L.-L.) muszę (...) nie, nigdy nawet słowa dziękuję, pochwały jakiejś (...), dlaczego, bo to przecież mój obowiązek.

Tak, usłyszałam kiedyś w czasie spotkania rodzinnego, że nie powinnam narzekać, bo przecież dobrze zarabiam jak na taaką pracę (...), nie wytrzymałam, wykrzyczałam informacje o mojej 
pracy, o tej niby fortunie, o uczniach, którzy z roku na rok trudniejsi (...) Reakcja szwagra? Spodziewałam się, że powie: no nie wiedziałem, może troszkę ze zrozumieniem użali się, (...) usłyszałam: chciałaś, to masz, nikt ci nie kazał iść na studia i to takie (...). Poniosło mnie, (...) do dnia dzisiejszego unikamy rozmów na tematy zawodowe.

Zarysował się niezwykle trudny wątek rozmów z nauczycielami związany z kwestią postrzegania prestiżu wykonywanego zawodu. Faktem jest, że wciąż zawód nauczycielski nie cieszy się powszechnym uznaniem, praca nauczyciela nie jest właściwie doceniana (nie tylko w opiniach, ale i w wymiarze formalnym - finansowym). Co ciekawe, nauczyciele „specjalni” częściej przeżywają negatywne emocje $\mathrm{z}$ tego powodu - sami niejednokrotnie poruszają wątek prestiżu nauczyciela „zwykłego” a prestiżu nauczyciela „specjalnego” - podkreślając, że zdarza się, że postrzegani są przez pryzmat swoich niepełnosprawnych (szczególnie niepełnosprawnych intelektualnie) uczniów i tym samym uważani są za gorszych nauczycieli, z mniejszymi kompetencjami:

(...) uczeń mało może, to i jego nauczyciel nie musi dużo potrafić.

(...) taka szkoła (specjalna - przyp. J. L.-L.), czego tam uczą, jak uczą, jakie efekty - żadne.

Najbardziej „poszkodowani” wydają się nauczyciele w szkołach masowych:

(...) mam ucznia autystycznego w klasie (...), koleżanki wiedzą, co to autyzm, (...) nie czuję ich wsparcia, cieszą się, że to nie na nich padło uczenie w tej klasie (...) za plecami śmieją się, że biegam na kurs, że kupuję książki (...).

Najlepiej natomiast radzą sobie nauczyciele uczący w szkole specjalnej, szczególnie ci, którzy określają siebie jako nauczyciela z powołaniem:

(...), na początku to mnie może i drażniło, ale potem, teraz - robię swoje, mam świetne dzieciaki, widzę efekty swojej pracy, ona sprawia mi wciąż satysfakcję, wciąż się rozwijam i... nie nudzę się, oj nie!

Ten sam nauczyciel, mimo że w swych opiniach tak odbiegający od wcześniejszych, dodaje jednak:

Pewnie, że miło by było, gdyby pieniążków było więcej w wypłacie, człowiek czułby się doceniony, dowartościowany, (...) może inni by więcej byli zaangażowani w pracy, gdyby nie musieli myśleć, jak dorobić (...), tak wiem o takich przypadkach i nie są to pojedyncze przykłady, a jak sama nie dorabia, to biegnie do domu, bo mąż idzie na fuchę (...).

Uposażenia to nie jedyny aspekt wątku finansowego wybrzmiewającego w badaniach. Nauczyciele nie tylko troszczą się o swą sytuację materialną, leżą 
im bowiem na sercu i warunki finansowe szkoły. Wskazują na nieustannie nie w pełni zaspokojone potrzeby w środowisku szkoły. Dostrzegają poprawę własnych warunków pracy w porównaniu z „kiedyś”, „dawniej”, ale nadal muszą dokonywać wyborów, co bardziej potrzebne (najczęściej wskazywano warsztat pracy, pomoce dydaktyczne, terapeutyczne, możliwość organizowania zajęć z uczniami), jaki zakup pilny, a co może jeszcze poczekać, by zaspokoić podstawowe kwestie, o luksusie nawet nie marząc. Przekonani są, że

(...) bogata... nie! nie bogata, wystarczy, że nie biedna szkoła, to lepsze warunki dla ucznia i dla nauczyciela, (...) środki na realizację pomysłów, atrakcyjne zajęcia, lepsze dotarcie do ucznia (...).

Liczne i różnorodne są problemy nauczycieli w edukacji uczniów. Jakby tego było mało, nauczyciele muszą poradzić $\mathrm{z}$ sytuacjami trudnymi, mającymi miejsce w relacjach w gronie współpracowników. Marzy się nauczycielom, by miejsce pracy było spotkaniem z życzliwym współpracownikiem, kolegą z pracy, na którego można liczyć w każdej sytuacji, z kimś, z kim współpraca to czysta przyjemność, „kto rozumie cię w pół słowa, kto myśli i czuje podobnie jak ty, kto realizuje te same cele”. I tak często bywa, nauczyciele stanowią niejednokrotnie zgrany zespół ludzi - partnerów w interakcji, kompetentnie dbających z równym zaangażowaniem o dobro dziecka jednakowo rozumiane. Są dla siebie wsparciem w sytuacjach trudnych, wspólnie budują rzeczywistość szkolną i wypełniają codzienność ucznia. Nie mniej jednak należy wspomnieć o sytuacjach zgoła odmiennych. Badani nauczyciele dostrzegają bowiem w gronie pedagogicznym swej szkoły konkurowanie o względy przełożonego, nie zawsze zdrowe współzawodnictwo, plotki, brak wspólnego frontu w działaniach $\mathrm{z}$ uczniami, pomniejszanie autorytetu nauczyciela, zabieganie o lepsze warunki własnej pracy, kosztem współpracownika. Motywów takich zachowań upatrywać należy zgodnie z opiniami większości badanych $\mathrm{w}$ prozie życia, w gonitwie za sukcesem zawodowym wiążącym się $\mathrm{z}$ chęcią podniesienia własnego prestiżu i poprawy sytuacji materialnej.

\section{„Robić coś dla siebie, dla uczniów, nie pod publiczkę (...)"}

Ostatnią kwestią, o której należy wspomnieć, dotyczącą wszystkich nauczycieli, jest ich obawa przed negatywną oceną. Nauczyciel poddawany jest nieustannie ocenianiu i to ze strony różnych podmiotów. Ocenianie przez przełożonego wpisane jest $\mathrm{w}$ rolę zawodową. Na wynik tej oceny nauczyciel pracuje codziennie, realizując swoje zadania. Kryteria oceniania są z reguły ściśle określone. Nauczyciel je zna, raczej o nich pamięta, zapewne stara się, by je spełniać, ale efekty mogą być różne. Życie i rzeczywistość szkolna niejednokrotnie pisze jednak scena- 
riusze, w których nie wszystko zależy od samego nauczyciela, jego wiedzy, umiejętności i kompetencji osobowościowych. W efekcie zawsze istnieje niepewność nauczyciela co do możliwości sprostania stawianym oczekiwaniom mimo usilnych starań oraz rzetelności oceny swej osoby i podejmowanych przez siebie działań.

Jestem dobrym nauczycielem, robię to, co do mnie należy, a nawet więcej, bo lubię swoją pracę, lubię dzieciaki. (...) nie da się wciąż myśleć - rób tak i tak, bo cię rozliczą, wtedy znika kreatywność, pojawia się sztywność myślenia, działania, a tak się nie da na dłuższą metę (...). Myślę, że tylko taki prawdziwy nauczyciel, po prostu robiący swoje, ma szansę być zadowolonym z pracy.

Robić coś dla siebie, dla uczniów, nie pod publiczkę (...), nie dlatego, że cię ktoś oceniać będzie

- to tylko fragment wypowiedzi nauczyciela, ale w pełni oddający jego emocje związane z sytuacją oceniania.

Ocenianie przez przełożonego to nie jedyna ocena, z jaką spotyka się nauczyciel. Każdego dnia doświadcza on opinii na swój temat, na temat jakości swojej pracy głoszonych przez rodziców uczniów. Zdecydowanie częściej badani nauczyciele deklarują, że są to opinie pozytywne. Rodzice doceniają nauczycieli za ich codzienną pracę, za wysiłek ponoszony w edukacji i terapii ich dzieci. Niejednokrotnie podziwiają wręcz nauczycielską cierpliwość i umiejętne podejście do tak trudnego przecież ucznia. Nauczyciele spotykają się z licznymi dowodami sympatii ze strony rodziców, cieszą się ich zaufaniem, bywają traktowani jak członkowie rodziny, przyjaciele, dobrzy znajomi (w ten sposób szczególnie często wypowiadają się nauczyciele realizujący nauczanie indywidualne ucznia w jego środowisku domowym). Nie brak jednak i ocen negatywnych wystawianych przez rodziców uczniów szkole, nauczycielom. Dominują tu opinie rodziców charakteryzujących się tzw. postawą roszczeniową, uważających, że „szkoła musi, ma obowiązek zająć się (...) dzieckiem, mają się na tym znać, (...) nie obchodzi mnie to (...) prawo jest po mojej stronie”. Niepokojące jest to, że rodzice ci doszukują się w szkole, w nauczycielach źródła wszelkich swoich problemów. Jednocześnie nie widzą potrzeby aktywności własnej w rozwiązaniu trudnej sytuacji, brak im otwartości we współpracy z nauczycielami. Najchętniej w ogóle nie angażowaliby się w sprawy szkolne (a często pojawia się wrażenie, że w jakiekolwiek nawet) swych dzieci. W ich opinii to wyłącznie szkoła ma otoczyć dziecko opieką, wychować je, wyedukować i objąć terapią. Przyczyn takiej postawy nauczyciele dopatrują się $\mathrm{w}$ bezsilności rodziców, w wypaleniu ich sił na przestrzeni lat, w poczuciu braku sukcesów w usprawnianiu dziecka, w ich braku wiedzy, umiejętności pomocy dziecku. Zachowanie rodziców tłumaczą także ich 
przemęczeniem, zniecierpliwieniem, żalem i rozgoryczeniem oraz poczuciem straty, brakiem możliwości realizacji marzeń i planów życiowych. To wszystko może świadczyć o braku pełnej akceptacji niepełnej sprawności dziecka i siebie $\mathrm{w}$ roli rodzica dziecka $\mathrm{z}$ niepełnosprawnością, co dowodzi zakłócenia przebiegu procesu adaptacji do sytuacji naznaczonej niepełnosprawnością dziecka. Konsekwencje tego stanu rzeczy ponosi sam rodzic, ale i jego dziecko, a także... nauczyciel, który w kontakcie z rodzicem doświadcza jego postawy życiowej i przeżywanych emocji, sam często mocno tę sytuację przeżywając.

Podobnie jest w codziennym kontakcie z uczniem. Nauczyciel w swojej pracy kieruje się rozumem, wykorzystuje swą wiedzę i umiejętności w sposób, który jak najbardziej korzystnie wpływa na podopiecznego. Współczesny nauczyciel jest świadomy swej roli $\mathrm{w}$ procesie nauczania dziecka ze specjalnymi potrzebami edukacyjnymi, wciąż doskonalący swój warsztat zawodowy, zaangażowany $\mathrm{w}$ swoją pracę. Wynika to nie tylko $\mathrm{z}$ oczekiwań rynku pracy, ale także z poczucia pedagogicznej odpowiedzialności za ucznia. A uczeń, jak już wspomniano, jest uczniem trudnym, odbiegającym od przyjętych szkolnych standardów. Szczególnie widoczne to jest $\mathrm{w}$ formach integracyjnych kształcenia specjalnego, gdzie w jednej klasie funkcjonują dzieci o różnym stopniu sprawności, różnych możliwościach rozwojowych i zróżnicowanych potrzebach edukacyjnych. Nauczyciel szczególnie w klasie integracyjnej musi stawić czoła konsekwencjom tej sytuacji. Nierzadko pojawia się kwestia posądzenia nauczyciela o brak obiektywizmu w ocenianiu uczniów, szczególnie tych z niepełnosprawnością. W opiniach uczniów nauczyciel jawi się jako niesprawiedliwy belfer. Musi sobie z tym poradzić. Zareagować na sytuację, że kiedyś być może nie wytłumaczono należycie uczniom pełnosprawnym, że przy ocenianiu kolegi z niepełnosprawnością bardziej uwzględnia się poniesiony wysiłek, poczyniony przez niego postęp, osiągnięcie sukcesu na miarę ograniczonych możliwości. Wtedy może mniej będzie krytycznych uwag uczniów na temat pracy nauczyciela, jego sposobu oceniania, może prowadzenia lekcji i stosunku do poszczególnych uczniów. Może wtedy nauczyciel będzie mógł spokojniej dobrze pracować, mając świadomość, że nie poddawany jest niesprawiedliwej ocenie ze strony uczniów. Sama kwestia oceniania nauczyciela przez ucznia, choć zawsze obecna w rzeczywistości szkolnej, nabiera nowego znaczenia, jeśli przyjmuje znamiona oceny formalnej stanowiącej jedno z kryteriów oceny nauczyciela przez przełożonego. W tej sytuacji pojawia się niebezpieczeństwo:

Uczeń ma mnie oceniać? Czy stanie ponad wszystko i będzie obiektywny? (...) Na ile to, jak ja go ocenię, wpłynie na to, jaką ocenę on mi wystawi? (...) A jaka będzie moja rzetelność oceniania uczniów, kiedy pomyślę, że być może to transakcja wiązana? (...) Unikajmy sytuacji, które niosą ze sobą jakieś zagrożenia. 
W tej wypowiedzi zawierają się wątpliwości nauczyciela i jego obawy związane z faktem, że jest oceniany, przy czym nie ma chyba większego znaczenia, czy jest to ocena formalna czy nieformalna w postaci opinii na jego temat. Nie jest także ważne. kto tej oceny dokonuje.

\section{Refleksje końcowe}

Zaprezentowane opracowanie ukazało szereg rozmaitych problemów obecnych w edukacji uczniów z niepełnosprawnością sygnalizowanych przez nauczycieli. Problemy te obecne w codziennej pracy nauczyciela, często ją utrudniają, niejednokrotnie wręcz zaburzają, co wymaga podjęcia odpowiednich działań, by tę sytuację zmienić. Niewątpliwie potrzebne są działania ze znamionami działań systemowych, wieloaspektowych, ciągłych i systematycznych. Warto też, by punktem wyjścia do ich podjęcia było wniknięcie w źródła problemów. Źródeł tych doszukiwać można się wielu, ich istota jest różna. Refleksja końcowa zakłada ogólne ujęcie kwestii uwarunkowań problemów w edukacji uczniów z niepełnosprawnością w opinii ich nauczycieli.

Głoszone opinie, postrzeganie edukacyjnej rzeczywistości uczniów z niepełnosprawnością być może zależy od samego sposobu spostrzegania inności ucznia $\mathrm{z}$ niepełnosprawnością. Bo czyż nie ma znaczenia to, jak ta inność jest rozumiana? „Inny” postrzegany jako „Obcy” wywołuje wrogość, skłania do zachowań zgoła agresywnych, odrzucających, pomijających go z jednej strony, z drugiej natomiast ktoś nam obcy, kogo nie znamy wywołuje obawy, lękamy się go, traktujemy go jako potencjalne źródło zagrożenia naszego bezpieczeństwa. W konsekwencji wykształcona zostaje negatywna postawa wobec osoby określonej jako „Inna”, co objawia się brakiem wiedzy na temat tej osoby, czy też wiedzą często wyłącznie potoczną, obfitującą w stereotypy i mity oraz negatywnym czy obojętnym stosunkiem do niej, przejawiającym się m.in. odczuwaniem wyłącznie negatywnych emocji w kontakcie $\mathrm{z}$ tą osobą, a także zachowaniami negatywnymi wobec osoby innej czy też unikaniem sytuacji, w której konieczne będzie wejście $\mathrm{w}$ interakcję z nią. Podobnie być może będzie, kiedy inność osoby traktowana będzie jako jej odrębność, odmienność. Na pewno osoba ta zwracać będzie na siebie uwagę swym odbieganiem od norm, przyjętych standardów i związku $\mathrm{z}$ tym będzie pojawiać się $\mathrm{w}$ kontakcie $\mathrm{z}$ nią myślenie o konieczności innego, specjalnego jej traktowania. Jeżeli zdamy sobie sprawę $\mathrm{z}$ tego, że właściwie nie wiemy, jak należy realizować tę specjalną interakcję, swoiste podejście, to może bardziej skłonni będziemy nie do podjęcia poszukiwań rozwiązań, co zmusza do wysiłku, lecz do wytworzenia pewnego dystansu w obcowaniu z „Innym”, uni- 
kania z nim kontaktu, a w razie konieczności pracy z „Innym”, traktowania jej w kategoriach wypełniania obowiązku i realizowania formalnych wymogów roli zawodowej. Zgoła odmiennie przedstawia się sytuacja, kiedy „Inny” postrzegany jest jako „Różny” - różniący się od przeciętnego ucznia, kiedy ta jego odmienność postrzegana jest $\mathrm{w}$ kategoriach wręcz egzotyki wzbudzającej zainteresowanie, ciekawość, chęć poznania. Obecność „Innego” jest wręcz pożądana, bo daje możliwość zaspokojenia głodu poznawczego, jest szansą sprawdzenia się w nowej sytuacji, obcowanie z nim stanowi źródło nowych doświadczeń, może wzbogacić. Takie podejście do inności ucznia z niepełnosprawnością stwarza możliwość ukształtowania się pozytywnej, pożądanej z pedagogicznego punktu widzenia, postawy nauczyciela, rokuje więc powodzeniem w pracy dydaktyczno-wychowawczej z nim (por. Pachowicz, 2013: 417-429).

Niewątpliwie rozumienie „Inności” to nie jedyne podłoże zróżnicowanego postrzegania problemów edukacji uczniów z niepełnosprawnością przez uczących ich nauczycieli. Należy także zwrócić uwagę na postrzeganie przez nauczyciela postaw społecznych wobec osób niepełnosprawnych, a także na prezentowaną przez samego nauczyciela postawę wobec niepełnosprawności i osób z niepełnosprawnością. Postawa ta, rozumiana jako społeczna, dotycząca ogólnie zjawiska niepełnej sprawności człowieka i ogółu osób należących do kategorii niepełnosprawnych, dotyczyć będzie także mikrośrodowiska szkoły, klasy szkolnej i kategorii uczniów z niepełnosprawnością. Nie można oczekiwać, że nauczyciel negatywnie postrzegający niepełnosprawność i osoby nią dotknięte, nagle, realizując rolę zawodową, zmieni swoje poglądy wobec świata, innych osób i siebie samego, a jeśli nawet nastąpi dostosowanie się nauczyciela do „poprawności polityki społecznej nakazującej odpowiednią postawę”, to pojawia się wątpliwość co do intencji i wiarygodności jego działań. Tylko pełne wewnętrzne przekonanie nauczyciela o słuszności idei równych szans $\mathrm{w}$ edukacji dzieci o zróżnicowanych potrzebach edukacyjnych oraz społecznej integracji osób z niepełnosprawnością od najwcześniejszych momentów ich życia pozwoli na ukształtowanie pożądanej pozytywnej postawy wobec ucznia $\mathrm{z}$ niepełnosprawnością, na zaakceptowanie jego inności oraz satysfakcjonujące spełnienie się $\mathrm{w}$ roli zawodowej jako nauczyciela ucznia z niepełnosprawnością.

Warto dodać, że będzie to tym łatwiejsze, im bardziej pozytywne będzie postrzeganie przez nauczyciela znaczenia edukacji, wykształcenia i aktywności zawodowej osób z niepełnosprawnością. Przekonanie o istotnej wartości wykształcenia i pracy $\mathrm{w}$ życiu osoby $\mathrm{z}$ niepełnosprawnością, o społecznych korzyściach płynących z normalizacji życia tej kategorii osób, nadaje dodatkowy sens pracy $\mathrm{z}$ osobami z odchyleniami w stanie zdrowia i rozwoju, wyznacza konkretne cele i ukazuje znane - choć zazwyczaj „wyboiste” drogi do ich osiągnięcia. 
Nie bez znaczenia dla nazywania i charakteryzowania przez nauczycieli problemów w edukacji uczniów z niepełnosprawnością jest także nie tylko samo ich zauważenie, nadanie im znaczenia, ale i świadomość możliwości ich rozwiązania, sprostania sytuacjom trudnym, przeświadczenie o własnych nauczycielskich kompetencjach, wiara w pozytywne zmiany systemowe oraz optymizm zarówno w sferze działalności zawodowej, jak i w codzienności życiowej.

\section{Literatura}

Apanel D. (2014). Rzeczywistość szkolna ucznia niepelnosprawnego i jego nauczyciela w edukacji integracyjnej. [W:] E. Bochno, I. Nowosad, M.J. Szymański (red.). Codzienność szkoły. Uczeń. Kraków.

Konstytucja Rzeczypospolitej Polskiej, 1997, Dz. U. 1997, Nr 78, poz. 483.

Lipińska-Lokś J. (2014a). Edukacja uczniów z niepetnosprawnościa - możliwości i ograniczenia. [W:] M. Magda-Adamowicz, I. Kopaczyńska, M. Nyczaj-Drąg (red.). Pedagogika wczesnoszkolna. Uczeń i nauczyciel w zmieniającej się przestrzeni społecznej. Toruń.

Lipińska-Lokś J. (2014b). Wspólna edukacja dzieci o różnym stopniu sprawności w opinii refleksyjnych praktyków, komunikat $\mathrm{z}$ badań wygłoszony podczas VIII Międzynarodowej Konferencji Naukowej z cyklu „Pedagogika specjalna - koncepcja i rzeczywistość”, Szczecin - Świnoujście - Ystad, 8-9.09.2014 r.

Pachowicz M. (2013). Uczeń niepetnosprawny widziany oczami nauczycieli klas integracyjnych. [W:] I. Chrzanowska, B. Jachimczak, K. Pawełczak (red.). Miejsce Innego we wspótczesnych naukach o wychowaniu. W poszukiwaniu pozytywów. Poznań.

Rozporządzenie Ministra Edukacji Narodowej z dnia 30 kwietnia 2013r. w sprawie zasad udzielania i organizacji pomocy psychologiczno-pedagogicznej w publicznych przedszkolach, szkołach i placówkach, Dz. U. 2013, poz. 532, z późn. zm.

Szumski G. (2006). Integracyjne kształcenie niepetnosprawnych. Warszawa.

Twardowski A. (2014). Barriers to social integration for people with disabilities. the polish experiences. „Studia Edukacyjne” nr 30.

Ustawa o systemie oświaty z dnia 7 września 1991r., tekst jednolity, Dz. U. 2004, Nr 256, poz. 2572.

\section{Current Problems in Educating Pupils with Disabilities in the Perception of Teachersengaged in Various Forms of Special Education}

\section{Summary}

Education of pupils with disabilities is integrated within the general education system in Poland. By law, it may be implemented in various forms of special education. Children with a disability may be educated both in traditional, segregated special schools and within special education pro- 
grammes in integrated settings. Among the options available for this type of education, there is integrative education (integrative classes), inclusive education (including individual pupils in primary school class structures, not integrative) and special classes in mainstream schools. There is also individual instruction provided for children with a disability who are unable to attend school because of their health status. However, pupils taught in their home environment by a school teacher are formally part of a school, belong to a class community, are visited by their peers classmates, and occasionally attend school. These elements of home education make it possible to recognise it as a form of integrative special education. Also in case of special schools, there are some signs of integration in the education of children with disabilities, as indicated by the so-called local integration, which implies openness on the part of special schools towards their local environment and their cooperation with mainstream schools functioning in the immediate vicinity. Children who go to these two types of school know each other, co-participate in organised events, such as parties, their teachers work together to jointly implement projects and are often mutually supportive.

Regardless of the form of education, children with disabilities always constitute a challenge both for their classmates and teachers.

Teachers experience a variety of problems in their daily work, which should not come as a surprise in light of the complexity of special education and its intrinsic prerequisite for special, unique methodology, all for the sake of very distinctive addressees, i.e. children with a disability. They have specific aptitudes and limitations, and hence the special educational needs, familiarity with which constitutes a basis for teachers' requirements towards children and for the applied working methods.

The problems of teachers who work with children with disabilities were diagnosed by means of interviews conducted as part of qualitative research on teachers' experiences, carried out in a group of teachers employed in special schools, in integrative classes, in mainstream schools with non-integrative classes or engaged in individual tuition.

The research made it possible to isolate some problem areas as seen by teachers of pupils with disabilities, related to:

a) legal regulations concerning education of children with disabilities (where positive changes are discernible throughout recent years, but some disadvantages are pointed out, mainly related to the frequency of introduced changes, which negatively affects the sense of stability of those involved);

b) provision of adequate technical conditions facilitating children's functioning at school (which is especially important in a situation of financial shortcomings and very specific needs of particular pupils);

c) organisation of the teaching process and orthopedagogical methodology (especially in classes with pupils of different levels of efficiency, where the teacher must meet different needs during one teaching unit);

d) teachers' competence (knowledge, skills, personality traits and mental readiness to work with 'non-mainstream' children) and methods of supporting teachers in their work);

e) cooperation between school and parents of both able-bodied children and children with disabilities, which, although is legally regulated in many ways, in reality, instead of promoting children's welfare, very often curbs the scope of constructive influence;

f) rather low social prestige of the teaching profession, particularly of special education teachers, who in public opinion need less competence because of the limitations of children with whom they work; 
g) financial shortcomings in terms of salaries for teachers and expenditures for the functioning of "schools for all children", and it is not about high expectations, but about comprehensive protection of real needs;

h) the sense of superiority of bureaucracy over didactic instruction in everyday life at school, which is particularly noticeable in the first and last weeks of the school year and in the case of applying for professional advancement;

i) fear of negative evaluation, both formal by the superior and less formal by pupils and their parents.

It is worthwhile to take a close look at the above mentioned problems, the more that each of the groups, to lesser or greater extent, affects teachers' work quality.

The form of education in which the diagnosed teachers work, their length of employment and the type and degree of addressed disability all differentiate the obtained results.

It is important to recognise these problems and make efforts to eliminate them from educational reality. 